DOI: 10.1515/ausfm-2017-0002

\title{
The Postcolonial Self and the Other in Béla Tarr's Werckmeister Harmonies
}

\author{
Lucian Tion \\ University of Singapore \\ E-mail: tionfiul@yahoo.com
}

\begin{abstract}
This work sets off to offer a polemical response to postcolonialist theories advanced by Homi Bhabha in his seminal work The Location of Culture, particularly to Bhabha's famous notions of ambivalence and mimicry purportedly used as methods of struggle against colonialism. Reading Béla Tarr's film Werckmeister Harmonies (Werckmeister harmóniák, 2000) as an allegory for the colonization of a former colonial agent in the guise of an ambiguously framed post-imperial Hungary now on the eve of Soviet invasion, I turn Bhabha's notions on their heads, and thus de-stereotype the simplistic hierarchy that sees the colonial agent dominate the colonized subject in a top-down approach. To achieve this, I bring into play KuanHsing Chen's notion of deimperialization as well as the psychoanalysis of Octave Mannoni in order to show that rather than being a straightforward misreading of the Other by an uninformed Self, the relationship between colonized and colonizer appears more like a failed attempt at acquiring the most basic knowledge of the psychological functioning of the Self on both sides of the colonized/ colonizer divide.
\end{abstract}

Keywords: Bhabha, Tarr, postcolonial, Hungary, Werckmeister.

Greatly simplified, the central argument in Homi Bhabha's (2006) postcolonial theory is that the "East" and the "West" cannot and should not continue to be regarded as disparate entities that came to a thunderous clash during the colonial period, but rather that both are ambiguous notions that, from a cultural point of view, have significantly interpenetrated each other and continue to do so. As part of this process, Bhabha claims, the "East" internalized the images and practices of their former colonial masters, following which, the colonized world, heretofore prey to both cultural and psychological ambivalence, was forced to undergo a schizoid split that was best resolved by its resorting to mimicry - among others - as a means of resistance. 
While I recognize the limited usefulness and undeniable veracity of this argument, I contend that exclusive focus on the methods of anti-colonialist struggle undertaken by and from the point of view of "Eastern" nations after their gaining of independence (ranging from armed struggle to mimicry) contributes to a further misunderstanding of the colonizer-colonized divide just as the Eurocentric postcolonial theory alone in the fait-accompli political status-quo of postcolonialism continues to biasedly tilt the balance in favour of the West.

As an alternative, I propose that the initial contact between colonizer and colonized deserves renewed analysis in order for us to understand the psychology of both sides involved in the equation. Particularly, and unlike most postcolonial theorists who focus on the tragic condition of the colonized subject, among which Bhabha features prominently, I argue that more attention should be given to the image of the colonizer, a subject, which was transformed over time into the stereotyped figure of the strong, dominant white male of Western-based stock, irresolutely led by an iron will to dominate and control. Far from sounding an apology to colonialism, and perfectly aware that the colonized subject - as Bhabha rightly observes - fell equally prey to heavy stereotyping, I argue that breaking these stereotypes is sine qua non to understanding the psychology of the colonial divide, and moreover, that in order to break these stereotypes one needs to address the moment, conditions, and mentality of the colonist at the ill-fated moment when colonialism began.

Even though the analysis is worth applying across the spectrum to the postcolonial world from Africa to Australia, in order to shed additional light on - as well as to raise the stakes of - postcolonialist discourse as it has been understood so far in terms of Westerners colonizing Easterners, in this paper I will drastically shift the geographical (as well as ideological) frameset to focus on Hungary, a country which had the (somewhat baffling) opportunity to play both the colonizer and colonized roles in the timeframe of well under fifty years; and a text that offers a unique reading of this predicament: Béla Tarr's Werckmeister Harmonies - a much (mis)interpreted ode to mystery, which I will attempt to unravel with the intent of highlighting the larger complexity inherent in postcolonialist theory in general.

To do so, I start by engaging with Bhabha's theory of ambivalence and mimicry, to which I later oppose the quasi-forgotten psychoanalytical theories of Octave Mannoni. Although susceptible of racism by today's standards, Mannoni's writings constitute - I argue - an interesting backdrop to Bhabha's, not only because they focus on the psychology of the first-time stand-off between the 
West and the "Other," but also because they belong to a point in time when postcolonial studies were only beginning to emerge as an academic field. Thus, Mannoni offers the somewhat "raw" edge of postcolonial studies, which had not yet been smoothed over by the later theoretical sophistication of writers such as Edward Said (1991), Homi K. Bhabha, and Gayatri Chakravorty Spivak (1999). To round up my alternative reading of postcolonial ambivalence, I bring in the argument for deimperialization put forth by Kuan-Hsing Chen, which I also use as an introduction to the discussion of Hungary's role as an in-between space, that will hopefully put a new angle on ambivalence as understood by Bhabha.

In the second half of the paper I move into an in-depth analysis of Béla Tarr's film, pinpointing the failings of Bhabha's theory to address the pragmatics of "real world" postcolonial politics, claiming that, ironically, Tarr's symbolism stands a better, if grimmer chance to represent postcolonial ambivalence than Bhabha's theory. While praising Bhabha's theoretical acumen minus his idealistic angle, I finally and briefly turn to Jean Luc Nancy and Luce Irigaray, both of whom I read as proposing a more realistic alternative to an otherwise perfectly valid ambivalence.

In his watershed critique of colonialism espoused in The Location of Culture, Bhabha correctly identifies the colonizer's reliance on "differentiation" as a means to the production of racist political policy: "The construction of the colonial subject in discourse, and the exercise of colonial power through discourse, demands an articulation of forms of difference - racial and sexual," Bhabha irrefutably argues, from where it follows that "the epithets racial or sexual come to be seen as modes of differentiation" (Bhabha 2006, 96). Furthermore, Bhabha moves on to correctly identify that the dichotomy between racial "superior" and "inferior" was enforced by colonial powers to such a degree that modernity itself seems to originate in the idea of civility, of being superior to the colonized Other: "Thus the political and theoretical genealogy of modernity lies not only in the origins of the idea of civility, but in this history of the colonial moment" $(2006,48)$.

Continuing from this position, Bhabha's placement of the colonial subject at the bottom of the social hierarchy set into place by the colonial powers allows him to formulate his famous theory of ambivalence, whereby the colonized was seen as "simultaneously embracing two contradictory beliefs" $(2006,115)$, which are, of course, those of the autochthonous, pre-colonial times, and those imposed by the colonizers.

Without refuting any of the valid arguments detailed above, my critique is centred on one question: Why, with such a clearly demarcating setup between Self and Other in place, and so much power endowed to the figure of the agent 
of colonialism, does Bhabha largely leave untouched the very figure of this agent in most of his postcolonial theoretical writings, even more so when the colonist himself was the harbinger of modernity?

In his famous chapter Of Mimicry and Man, Bhabha uses Lacan's notion of the Imaginary (corresponding roughly to the early formation of the ego in Freudian terms), stating that there are "two forms of identification complicit with the Imaginary - narcissism and aggressivity," which, he argues are "precisely [the] two forms of identification that constitute the dominant strategy of colonial power" (2006, 110). By paralleling the Lacanian mirror stage in the ego's development to the discovery of the Other by the Westerner and vice versa, Bhabha leads us to infer that the alienation experienced by the Other in the relationship with the colonial power imbues the Other with an ambivalence between a desire for sameness and a consciousness of difference, which ends up leaving the Other in a state of what Bhabha calls using Lacanian terminology "lack."

This is a central issue in the argument as this "lack" is repeatedly invoked by Bhabha as a paramount reason for the Other's pursuing of the action of "mimicry" in response to - we understand - the forced need of integration of the colonized subject into both the colonial and the postcolonial world $(2006,107)$. This contrasts to other interpretations resulting from "lack," which a theorist like Kuan-Hsing Chen (2010) simply refers to as "frustration" and "resentment," and which Nancy (2002) calls "passing between," as in the meaning that gets lost in (un)attempted communication.

Be that as it may, Bhabha identifies the most important reaction to colonization as that of mimicry. Mimicry according to Bhabha carried along, at least at first, a sense of mockery. To illustrate this, he quotes Naipaul, who reminisces on his past as a child growing up under colonial rule: "We pretended to be real, to be learning, to be preparing ourselves for life, we mimic men of the New World" (2006, 125). However, what for Bhabha in the beginning had only a parodic effect, the mocking and authority-disruptive function of mimicry $(2006,126)$ seems to have transmuted into a plain Baudrillardian simulacrum (1994) in the postcolonial era, in which the mockery edge of mimicry was carefully polished off.

While Bhabha correctly notices that whole sections of colonized populations used mimicry to get ahead in a (recently made) "white world" by copying "white ways" while simultaneously making a fool out of the material that is mimicked, it seems that postcolonial societies adapted (and adopted) - sometimes wholesale - pieces of legislature, political organizations, and, most certainly, economic policies exclusively used beforehand by the colonizer. Therefore, isn't it safe 
to assume that mimicry in post-colonialism lost its mockery angle altogether to become a tool for development, industrialization and modernization that excolonial subjects have eagerly and unabatingly embraced? Furthermore, hasn't the post-colonial world lost the ambivalence that Bhabha identified as a result of Lacanian "lack?" And hasn't mimicry as a subtle tool for building identification that used to offer ex-colonial societies respite from an overdrawn and anxietyridden identity crisis, disappeared to usher in the repercussions and effects of the same now unresolved crisis?

It becomes more and more evident that postcolonialism is an age of postmimicry, since mimicry itself became the sacred agent of capitalism in decolonized postcolonial societies. It is my contention, therefore that Bhabha's notion of mimicry in postcolonial capitalist systems changed roles from being a parodic tool to becoming an object of quasi-veneration by allowing the formerly vilified Other to engage in a role-reversal process of simulation as symbolic punishment for the intrusion of colonialism. In other words, postcolonialism, in the time-honoured fashion in which any revolution is fated to devour its own children, turned colonialist tactics into its own weapons, promoting a weapon of resistance into the seat of power, and ultimately into the means of domination. I am speaking, of course, of the transfer and transformation of capitalism from a mode of exploitation to a mode of production, and from a weapon for conquering without to one of dominating within.

Finally, to return to the second term of the equation, which was left out throughout Bhabha's narrative by way of an issue which, as we shall see, will become central to Chen's argumentation: Wouldn't the perceived absence of the Other from the colonizer's sphere of influence mirror the same psychological "lack" experienced by the Other for his old colonial master during colonial times? And how were the colonizer's Self and the Other constituted before their encounter took place, if this was as influential on their subsequent constitutions as Bhabha claims it was, and rightfully so?

If Bhabha does not address this question, it is because he considers that the contact between colonizer and colonized led to an ambivalence, which forever changed, for better or worse, the identity of the parties involved; an ambivalence we should alone try to first accept and later understand. Therefore, unlike Chen, who makes it his business to focus on the repercussions following this contact, Bhabha does not consider the causes to be as significant as the effects, valuing pure acceptance over reason. However, I claim that in order to understand this postcolonial ambivalence as Bhabha wants us to, it is essential that we first 
understand why the fateful encounter between the two parties ever took place in the first place.

It almost goes without saying that the real crisis of postcolonialism does not lay in the rebuilding of an identity that has been irremediably lost to the cruel rape of colonialism anymore, which practically helped efface the former identity of colonial subjects through a capitalism subsequently encouraged and enforced by the very subjects it was formerly forced upon. It has become apparent rather that the crisis has never left the (psychological) space of the colonizing subject - the white male colonizer - who was the promoter of these values in the first place. Moreover, it seems that the moment when this crisis first reared its head was during the pre-colonial age of Enlightenment, more precisely, during the very moment of encounter between what I shall heretofore call the European "Self" and the "Other," a contact which offered both parties a unique opportunity to enter into a precious relationship of knowledge with themselves.

However, as history itself stands to prove it, it is relatively clear to see that this opportunity was wasted, and the encounter ended for both the colonizing white male as well as for the colonized subject in total failure: Failure in attaining knowledge of the Other (on both sides of the divide), as well as failure of attaining self-knowledge. The lack of cooperation and the breakdown in communication, which later became a staple of colonialism is thus, I contend, not necessarily only a failure to understand the Other, but the more tragic flaw of not understanding the Self.

There is consequently some room for doubt that the solution to postcolonial resentment characterizing decolonized societies will spring from an understating of "ambivalence" or "mimicry." It seems rather that these otherwise valid and altogether real values have currently become so ingrained in a postcolonial modus operandi that it is difficult to tell them apart. And even if we were able to identify them, it seems hardly likely in a capitalism embraced more aggressively by the ex-colonized than by their former masters that these concepts would become useful in shedding light on the still subsiding differences between the irking categories of the "West" and the "Third World." Just as no unrequited relationship (of love or colonization) would be fairly judged without examining the intentions and feelings of both parties, an analysis of the typologies of both sides involved in the colonial discourse needs further undertaking. In order to perform such an analysis, I shall finally turn to Kuan-Hsing Chen's theory of deimperialization.

Speaking about Asia and Taiwan in particular, Chen contends that in the 
aftermath of colonialism "The West," as much as "The East," are responsible for doing some individual soul-searching in order to properly understand the reasons for, and the effects of actions undertaken during colonialism: "Postcolonial cultural studies is at an impasse," Chen writes: "the central problem lies in its obsessive critique of the West, which bounds the field by the object of its own criticism" $(2010,1)$, and his study entitled Asia as Method: Toward Deimperialization is a veritable textbook for dealing with colonial-generated trauma in need of confrontation. However, unlike other theorists focusing on a militant approach replete with criticism of the West, Chen suggests that the West itself was traumatized by the loss of the colonial sphere of influence, as much as the East was shattered by Western interference.

He then proceeds to suggest that the work of decolonization hinted at above, while absolutely necessary, will not bear fruit alone, without a parallel work of what he calls deimperialization, a process produced in the centres of power of the former colonizers that needs to be experienced in tandem with that of decolonization. Thus, the loci of economic as well as symbolic power encapsulated in such notions of topoi as "London" or "Paris" would need to undergo a semantic transformation that would lead to a de facto renunciation of power. Nothing but a symbolic as well as practical ideological cleansing, Chen argues, would render the loaded notions of these psychologically-charged geographies neutral again. ${ }^{1}$

Chen holds that the nationalist response to postcolonialism that many Asian countries quickly jumped to embrace in the wake of independence acts as nothing but a stumbling block to these countries' sharing, but, more tragically, gaining of knowledge of the region and of themselves. He further argues that in order to move forward, a nation needs to examine, not negate nationalism (Chen 2010, ix), as well as to "move beyond the limits of colonial identification on the one hand, and the postcolonial politics of resentment on the other hand" (Chen 2010, xiii). Ironically, Chen's is the same project that Bhabha holds as paramount to understanding the postmodern postcolonial world. However, unlike Chen, despite his striding both worlds he is trying to bring to coexist peacefully, Bhabha fails to see the enormous fear, self-blame, and disorientation that the West, along with the East, was experiencing at the dawn of the postcolonialist era. Influenced

1 The perfect example of deimperialization not taking place after decolonization is currently (not) going on in Russia, itself a part of the unofficial former Soviet empire that Tarr's film deals with as we shall soon see. With Moscow adamant to renounce ideological power over its former yet unacknowledged colonies (some of which were de facto incorporated into the USSR), a current trend of resurging claims over territories adjacent thereto led to annexation and war in one area, and involvement in other wars of supposed "spheres of influence." 
by the ideology of armed revolutionary struggle promoted by Franz Fanon (1968), which was only too understandable at the time, Bhabha seems to at least partially get caught in the quagmires of resentment that Chen warns against. Therefore, Bhabha fails to identify that a probable cause for the West's unwillingness to give up the seat of symbolic power Chen clearly sees as a continuing source of discord, stems from the West's own difficulty of processing the repercussions of trauma related to the ambiguous as well as ambivalent colonialist project. Therefore, it is paramount, I argue, not only to understand the postcolonial condition in general, but to analyse the roots of the process that led to its appearance in the first place. More taken for granted than actually discussed within the field of postcolonial studies, the remaining part of this paper attempts an analysis of this process.

"I was forced to realize that the colonials were reluctant to admit that they understood the native as well as they in fact did," writes Mannoni in 1956, "and I saw that the problem for human beings, however much they differed from one another, was to acquire, not the ability but the will to understand each other" (1956, 34). Maybe I should have used this quote belonging to Octave Mannoni to start off this paper. However, Mannoni's falling into disrepute due to his ambiguous, if not racist take on colonialism at the time of his writing in the midfifties, when the West was in full process of decolonization, risked to put an overly essentialistic, if not dangerous twist on my argument. The reality is that Mannoni, a French psychoanalyst, who spent half of his life in colonial Madagascar before independence, is one of the first products of nascent postcolonialism who, heavily influenced by Freudian, Adlerian and Jungian theories, dared to bring, albeit with some naïveté, the figure of the colonizer back into the equation, a move largely avoided by later theorists of either Western or Eastern origin.

Writing, as stated, during a transitional time, when neither attitudes nor terminology were still firmly in place (he uses the term "racialist" to refer to "racism"), Mannoni, however, plunges deep into psychoanalysis to examine the contact - particularly the first-time contact - between the white and black races with some (to say the least) curious conclusions.

One of the first concepts he unearths during his analysis of tribal societies along the Malagasy of Madagascar due to the all but forgotten work of German psychoanalyst Fritz Kunkel is that "primitive" societies (I use the same inverted commas as Mannoni) are based on psychological dependence, in the sense that family kinship alters the structure of society altogether, turning humans very reliant on both the other members of society, as well as on the parental couple $(1956,63)$. Not a stranger to this concept, the modern white man, Mannoni writes, 
traded abandonment of the family (or the family's abandonment of himself) for "progress," which Mannoni identifies as an advantage over the "weakness" of the "primitive" society, which the white colonizer exploited.

What he proceeds to say after this quasi imperialist blurt, however, is interesting: A reverse view of dependence seen from the Malagasy point of view - thus, the independence of the white male - signifies the absence of a soul. For the Malagasy, the soul resides in the very dependence of the members of the commune upon one another, and it manifests itself in the dependence on the parental couple and veneration of the ancestors, which are both absent in the "independent" European. Thus, to the Malagasy it is the European who has the inferiority complex, and not the other way around (Mannoni 1956, 74).

In continuation to this argument, Mannoni proceeds to look at literature as a paradigm for his theory, in essence identifying an extension thereof. Using Daniel Defoe (1883) as a metaphor, Mannoni suggests that the impulse for colonial exploration came from what he calls a "misanthropic neurosis," the cure of which is the process of self-negating and self-testing, which proceeds to bring out the self in a reinforced state, and in a position to rule over others. In other words, Mannoni contends that the colonial sought to invest the self with power that would ultimately bury the initial neurosis $(1956,100)$, and even the possible inferiority complex sprung from the dependence on the parental relationship. (Recall Robinson's break with his father's command to stay away from the sea, and, how when the storm hits, he feels he is punished by heaven.) Ruling over others is therefore an extension, and externalization of a distorted attempt at ruling over the self. And winning the fight over the Other is thus but an illusory confirmation of self-control.

The European in relation to the Malagasy is therefore a person in conflict with his own soul (might we dare to read Self?) because of the (Western) societyimposed dictate that forces one to acquire independence. This can only be carried out by severing what for the Malagasy is considered sacred dependence on the parents. Therefore, from this angle, colonialism emerges as a childish phantasy of an adult, who hasn't emotionally grown up. Possibly rooted in an unsatisfied child's desire to escape his environment, whether this be the father's authority or that of civilization as a whole, what Western critical literature extolled as the "initiatory voyage" might be, in Mannoni's reading, "a flight from mankind," along which any "intrusion must be guarded against" $(1956,101)$. He goes so far as to read "some of the semi-human creatures the unconscious creates, such as Caliban or the Lilliputians [as] their creator's desire to denigrate the whole 
of mankind" (1956, 101). "The 'case' of Defoe," Mannoni writes, "is one of misanthropy, melancholy, a pathological need for solitude, the projection of his faults on to others, [and] a sense of guilt towards his father" $(1956,103)$.

To finish, Mannoni takes his own version of Freudian theory to its logical conclusion, namely that the encounter with the Other, which invariably takes place during this infantile flight, becomes a projection "on to the colonial inhabitant [of] our deeply-hidden fears and desires" $(1956,198)$. Interestingly, Mannoni also hints that being confronted with the Other for the first time (a moment which he aptly terms "the beginning of all misunderstandings between human beings") can also become the source of powerful revelations, as "sometimes, before this highly revealing mirror, the white man comes to see himself as he really is." But he warns that "very few men are capable, when they are at length obliged to acknowledge the existence of other people, of recognizing in themselves what they never suspected was there, without an outburst of the fear, hatred, or harshness they had directed towards an aspect of themselves, which in very truth they had wanted to ignore" $(1956,199)$. Wouldn't it be interesting to reconsider Bhabha's theory of ambivalence at this stage with the concepts of parent-related guilt, escapism and self-conflict thrown in together with the already present colonized trauma and dependency?

So, in the end, what had started out as a flight from inadequacy and inferiority turns into a monstrous projection of the very fear the white colonizer was trying to escape. Although Eurocentric and controversial, Mannoni acknowledges in his last chapter optimistically entitled The Unity of Mankind that "by and large our image of [the colonized] is simply a reflection of our own inner difficulties [...] and the racialist reactions of the white man to the black are the product of elements already present in his psyche" $(1956,197)$. So, it comes as no surprise that Mannoni concludes his analysis with the chilling claim, which today would hardly see the light of day without the tag of racism quickly attached hereto, namely that in the black man the white man "reveals his secret self, not as he is, but rather as he fears he may be. The negro, then, is the white man's fear of himself" (1956, 200).

Although, as Fanon (1968) correctly pointed out in his criticism of Mannoni, the latter fails to understand the colonial subject almost entirely, and is misguided in his Eurocentric apprehensions thereof (Chassler 2007), Mannoni's book dares to approach colonialism from the (until then) untried psychological tradition, and by doing so, opens a road, which does not seem to have been much trodden after the collapse of colonialism, when postcolonial studies - itself a field ridden 
with self-protective political correctness - did not allow much daring theoretical speculation to be woven around a very polarized dichotomy.

Moreover, it seems that Mannoni's vilified Eurocentric attitude still represents a point of departure for the more contemporary postcolonial theories of Nancy and Irigaray (2002). Even though neither of the two theorists is considered primarily a postcolonial writer, with Nancy coming from a philosophical tradition and Irigaray from that of feminist studies, both Nancy's theory of "being with" and Irigaray's emphasis on co-being, as we shall see, owe their repositioning of the Self-Other relationship, among others, to Mannoni's psychoanalytical work. Moreover, it is the rifts that Mannoni makes evident in his analysis of the colonial self and the foreshadowing of a pre-colonial condition characterized by inner conflict that brings Freudian projection into postcolonial studies. Thanks to Mannoni we may begin to reconsider the firm teleology we nowadays attach to the colonial project, at least in its opening phases. And finally, Mannoni helps us understand, I argue, that the colonial Self is not a machine-like, simplistic entity guided by the self-righteous precepts of a mission civilisatrice, which is somehow innate to the white Western colonizer. If we allow Mannoni the mistakes inherent in his time, we might even be able to see him as a precursor of Bhabha's ambivalent condition, to which the angle of human emotion, contingency and uncertainty can finally (and most necessarily) be brought into play alongside the circumstances surrounding the ill-fated relationship between the West and the Other. Far from being a closed case of predetermined fate, as Enlightenment ironically started to think of it thereafter, the hierarchic relationship between Self and Other, as seen through Mannoni, temporarily reveals its self-questioning and self-doubting character, which never entirely left the racial divide thereafter. However, only by reverting to a time prior to colonization, and by plunging into an analysis of the determinately more complex surroundings of the initial phases of colonialism, can we hope to understand why Bhabha's otherwise valid ambivalence takes the form that it does today. Weaving together the loose ends of contemporary postcolonialist discourse becomes therefore directly contingent on our understanding of earlier theorists and schools of thought that, in the manner of Nancy and Irigaray, necessarily pit against one another opposing concepts in order to sublimate them into a later coexistence.

So far, we explored the hypotheses that the subconscious fear of the Self may be actualized in colonialist representation as dominion over the Other; as well as the political theory of the Self and the Other as loci of the "folding" of projection and raised the question of whether unfolding was reversible and under what 
circumstances. In the following I would like to simplify the picture by cutting out the projection of the Other from the equation altogether, and focusing exclusively on the (colonial) Self in the process of decolonization - thus at the stage of the unfolding of projection (in Mannoni's terminology) or qua deimperialization (if we are to follow Chen).

For this reason, I am positioning the Hungarian space as a possible topos, where one could look at the Self and Other as identical, the argument being that, historically speaking, Hungary has fulfilled both the role of the colonizer (during its association with the long-lived Austro-Hungarian Empire) and colonized after the Soviet takeover of Eastern Europe completed in 1949, and particularly after the bloody repression of the Hungarian uprising of 1956. In order to undertake such analysis, I portend that cinema, and not necessarily only postcolonial cinema specifically addressing issues raised or effected by postcolonialism, but the cinema of such apparently disconnected auteurs as Béla Tarr constitutes a powerful tool of investigation of the relationship between Self and Other in the colonial/postcolonial context.

Combining Chen's political proposition with Mannoni's psychological position provide me with an entry point for my analysis of Werckmeister Harmonies, which I read as an alternative to Bhabha's space of ambivalent in-betweenness. While Chen uses the geographical space of "Asia" as a conceptual label to engender future understanding of the disparate selves of separate Asian countries affected by colonialism, I argue that Tarr's film similarly acts as a call for self-knowledge in the likewise fragmented space of Eastern Europe.

Ignored by postcolonial studies until the much-needed work of film theorists such as Anikó Imre (2016), Eastern Europe, and therefore intra-European colonization, has only recently been compared to the one that took place overseas. ${ }^{2}$ Following this line of thought, my argument is that Eastern European history easily permits us to consider pre-World War I territories in this part of the world as colonial subjects under the suzerainty of the region's three major empires: the Tsarist Russian, the Ottoman, and the Austro-Hungarian with ensuing similar nationalisms surrounding the construction of their identities in the aftermath of WWII, just as in the Asian case.

I therefore posit that, even though not made apparent in the film, Hungary acts as a paradigm for any one of the multitude of "statelets" that make up the fabric of

2 For works arguing both for and against the integration of Eastern Europe into the broader area of postcolonial studies see the writings of Maria Todorova, Anikó Imre, Katherine Verdery, Michal Buchowski, Niel Lazarus, and the more foundational studies on Central-Eastern Europe by Larry Wolff, among many others. 
multi-ethnic, conflict-prone Eastern Europe. Moreover, as noted above, to stage the ominous encounter between the Self and the Other in Hungary is to allow the Self to see itself as an Other, since post-WWII Hungary quickly changed tracks, turning from an ex-agent of colonialism into the victim of colonization. There is no better setting, therefore for the dramatic staging of both Bhabha's ambivalence, Mannoni's inner conflict, and Chen's concomitant decolonization and deimperialization.

Tarr sets the action of his film in a small Hungarian village absorbed in fog, as much as its inhabitants are absorbed in themselves. We descend into this seemingly isolated space situated somewhere in the infinite Hungarian plain through the eyes of János, a slow-witted, yet extra-perceptive young postman and errand-runner for György Eszter, a prominent representative of the now falleninto-disrepute village aristocracy. In a village, where boredom reigns supreme and where everyone keeps themselves busy through either drink or by entertaining prophecies of impending doom, János and his employer seem the only "sane" pawns in an otherwise dangerous game played by the villagers as if in a stalemate with an ill-intentioned demiurge.

This becomes even more apparent with the arrival of a bizarre circus featuring the carcass of a dead whale and an enigmatic prince as attractions. Based on hearsay from a nearby village, where the circus had initially "performed," and where allegedly the church horologe was suddenly put into motion after hundreds of years of inactivity, the local doomsayers associate the circus with unmitigated disaster. Despite their warnings, János, the embodiment of curiosity par excellence dares to wander wide-eyed into the circus truck parked in the middle of the central square of the town.

The placement of this truck in the central square is far from incidental. Traditionally, town and city squares in Eastern Europe served as places for display, dissemination of information, exchange, gathering and communication. What I argue is that this particular setting in Tarr's movie acquires a double metaphorical significance. First, by virtue of its being centrally situated in the middle of the village, the square can be linked to the inner core of the community, and by extension, to the communal self-consciousness of an almost Freudian form of Ego. Furthermore, I argue that the open, agora-like nature of the village square engulfed in mist signifies the unknown nature of this conscience, and judging by the apprehensive way, in which the villagers approach the square in the final scene, the inability of the community to know its own collective self. The truck intruding into this space, therefore, serves as an invitation for the villagers to liaise not only with the unknown Other, but also with their own unexplored consciousness. 
Additionally, there is more in the film to invite this particular reading. The object of attraction on display in the circus truck is a colossal whale. Aside from carrying implicit marks of exoticism, which create a further link between the circus and the mysterious Other, the whale taking up the space in the midst of the villagers' symbolic collective consciousness suddenly becomes an agent inviting the villagers down the path toward self-exploration. Suddenly, Mannoni's words ring prophetic, as we realize that the only way for the colonizers to acquire selfknowledge is through the intermediation of the (exotic) Other. Furthermore, the literal filling of the empty communal space with the arrival of the gigantic whale is, I argue, the fulfilment of an unconscious desire of the Self for self-knowledge.

Overcome by fear, however, the villagers ultimately refuse to partake in the process of self-discovery, a journey that is only completed by János. For János, the Other loses his frightening value, and becomes an object of (self) contemplation. The glacial eye of the dead sea monster acts as a mirror reflection of the self, and recalls another anthological screen moment, namely that of the end of La Dolce Vita's (directed by Federico Fellini, 1960) morning excursion on the beach, where the eye of the dead octopus similarly acts as a reminder of impending death. In Tarr's film, János's bemused staring into the eye of the whale seems to substantiate nothing more than the commonplace similarity between the Other and Self.

However, by establishing contact with this eye, János becomes himself an "Other" in the eyes of the villagers. It is the conflict between the villagers' misapprehension of the Other and their own fears that escalates into violence. Unable to perceive the Other as a benign object, as János does, the crowds prove incapable of stemming the tide of their fears and proceed to destroy parts of the town, while the prince's words resonate in a sombre voice-over: "What they build and will build is delusion and lies. [...] They think [read build] because they are afraid." Construction, the prince warns, is always a process, thus incomplete. Ruins, on the other hand represent the end of a process, and so they are always complete.

The crowds turn the impoverished town hospital into ruins, only satiated by their own abscess of violence, and finally file silently back into the streets, a monster again put to rest like the whale in the town square. Tarr's message seems clear enough: Violence alone, the will to destruct is the only evidence the crowds can produce to having a conscience. "Let's have the courage to understand this," Nietzsche entreats his readers at the very end of the Genealogy of Morals: "man will sooner will nothingness than not will” $(2009,135)$.

In Mannonian psychoanalytical fashion, the crowds do not fear the Other but themselves. The self alone is the repository of unavowed, unacknowledged fears, 
which rise into the conscious as forms of threat to the stability of a mythical and illusory pure origin, which exists as such only in the village's imaginary.

Werckmeister Harmonies is ultimately an allegory of not only the failure to understand the Self, but a necessity to nullify it, à la Nietzsche, because it is (or we think it is) inaccessible. Furthermore, when the empty, misunderstood Self (in the guise of the villagers) is confronted with an Other (the circus), the Self's tendency is to abolish, destroy or at best conquer this Other in order to establish a form of illusory control over it. Not dissimilar to Mannoni's theory, this is, I argue, the nature of the first encounter between the Westerner and the Other in the ill-fated saga of colonialism. The metaphor offered in Tarr's movie is that the Other needs to be destroyed, eliminated, and the process of destruction forgotten (drowned in a river of alcohol) for the Self to preserve the state of ignorance, which is the only condition it can admit to as an acceptable form of existence.

To return to Bhabha's ambivalence and the position held by Hungary in the process between Self and Other, I argue that Bhabha presses his "contingent inbetweenness" too far, undoubtedly out of a certain (un)acknowledged desire to push the agenda of postcolonial studies in a different direction. The problem with this stance is that despite all its promising usefulness for postcolonial studies, it hardly characterizes the real, boots-on-the-ground postcolonial world he takes issues with.

What Tarr successfully shows in his film, on the other hand, is that the interstitial postcoloniality that Bhabha unrestrainedly extols as a way out of neocolonial impasse is a world full of gaps, ignorance, internecine fighting and powermongering, which hardly matches the idealism of Bhabha's "in-betweenness." In other words, if post-imperial, pre-Soviet-invasion Hungary can be seen as an interstitial space defining the postmodern condition that Bhabha believes defines the postcolonial world, Tarr offers a reality check, in which resurgent nationalism, confusion, chaos and violence unreservedly strangle the last drop of life out of Bhabha's power of ambivalence and mimicry to assert their status as standardbearers in a new, interstitial world. Therefore, despite wishing that "[this] side of the psychosis of patriotic fervour, I like to think, there is overwhelming evidence of a more transnational and translational sense of the hybridity of imagined communities," (2006, 7) Bhabha's visionary project of championing inbetweenness unfortunately fails the break-in test of the postmodern condition. If we are to believe Béla Tarr over Bhabha, power goes so far as to regain some of its Nietzschean flavour by being unapologetically transmitted back into the hands of the shameless "patriots" that Bhabha dismissingly relegates to some bygone, and 
not only imagined, but fantasized Andersonian past. Reading Bhabha next to Tarr therefore makes us more aware that the latter understandably falls prey to his own condition as a self-titled representative of the hybrid condition in a world, which has yet to come to terms with its real but unacknowledged hybridity.

Therefore, I hold that while Bhabha's theory of hybridity holds significant currency in the postmodern world, its applicability in a realpolitik context proves to be still limited and not sufficiently substantiated in order to gain - as Bhabha undoubtedly desires - valance as a political modus operandi.

Chen posits that decolonization is but a one-sided action undertaken by the formerly colonized subject in the geographical area that was exposed to colonization, and not a double-sided approach, which should involve the colonizer. For a complete reversal to the pre-colonial status quo to take place, Chen argues, there needs to be a similar deimperialization action taking place within (at the centre of) the colonizer's seat of power. Such a process, he argues, did not only not start anywhere in the postcolonial world, but awareness of the necessity of such a process taking place hasn't even entered the former colonizers' consciousness $(2010,7)$.

In Tarr's film, the encounter between villagers and the whale is telling. At the very centre of a former colonial power, who has not undergone the necessary work of deimperialization (a mixture of grieving and repentance), comes the Other - the Soviets - and affects it in the same way as it - Hungary as a colonial power - previously affected other Others. In this scenario, the perpetuation of misunderstandings, un-knowledge of the Self, and destruction of each other in lieu of self-destruction continue to plague the relations between Selves and Others in a multiple network that extends on and on ad infinitum, with the Other playing the part of the Self for another Other and vice versa. Colonialism is thus, in my reading, the failure of the colonizer, ethnocentric-self to understand its own Self, just as it equally is the failure of the Other to understand their self in relation to the Other. The result of such misappropriation does not seem to lead, in practical terms, to the rule of hybridity à la Bhabha. According to Béla Tarr, for reasons that fear continues to make complex, the encounter between the Self and the Other, seen as its mirror image, proves unbearable to the Self. Sadly, Tarr's films show that only a Self nurtured by myth, ignorance and fear, a Self able to rule over others through the networks set up by the capitalist mode of production seems capable of validating its existence.

There are alternatives to this continually reproduced moment of initial encounter between Self and Other, which capitalism has made into a modus 
vivendi, alternatives that bypass both Bhabha, and even Chen's deimperialization tactics. Even though he may well take his characters from a world dominated by Bhabha's ambivalence, Nancy (2002) furthers the idea that meaning can be made in the process of being with each other, and it does not necessarily have to precede the otherwise misunderstood relationship between the two. Furthermore, Irigaray makes yet another alternative even clearer, as she advocates for gender relationships, in which their members do not have to strive for either equality or opposition, but simply "respect each other's differences" $(2002,103)$. And she concludes somewhat alongside Chen that "to go in search of oneself especially in the relationship with the other represents a work not yet carried out by our culture" $(2010,43)$.

What is clear from the writings of these theorists, and further strengthens Chen's point is that direct opposition to colonialism and Otherness does not make a harmonious relationship between ex-colonizer and ex-colonized. What postcolonial humanity needs to learn is either a new language, through which the unacknowledged Other can start to express oneself (a concept again at work in Luce Irigaray's theories on sex), or a re-evaluation and re-appropriation process, through which the two "exes" can accede to self-knowledge.

Idealistic as they may be, Irigaray and Nancy's models offer as much optimism for the future of postcolonialist studies as Homi Bhabha, even though they are not considered postcolonial theorists. Whether it is "co-being," as in the writing of Irigaray on the couple, or "being-with," along the lines of Nancy's theorization of the future of the political world, it takes a combination of partially misread film artists such as Béla Tarr and the repositioning of older concepts to sound the alarm bells for the demystification of the past and a call for self-knowledge. It is only such a repositioning, in which certain actors previously didn't figure, that may bring about the much sought-after change in the field.

That and the inclusion in the field of ambiguously ambivalent Eastern Europe with its history of colonialism and postcolonial segregation followed by isolation and vicious post-communist nationalism, may be one of the possible ways to help us rethink both the Western/Other divide, as well as the field of postcolonial studies as a whole. If Chen's idea of a synchronous decolonization and deimperialization could make Asia itself into a method for the overcoming of postcolonial "impasse," then Eastern Europe may not be far (speaking in utopian terms) from its own "method," through which its "statelets" could set themselves forth to investigate their own nationalisms (thus blown-up sense of Selves) and overcome fear, which is the sine-qua-non for any subsequent hope of living in "co-being" rather than in mutual suspicion of one another. 
There is a parallel plot in Werckmeister Harmonies, which also gives the movie its title. The musicologist and fallen aristocrat György Eszter is attempting to prove that musical theory as we know it today, specifically musical tonality, is based on an illusion that had been adopted into common practice since Bach embraced the musical theories of Andreas Werckmeister, a $17^{\text {th }}$-century music theorist. The so-called Werckmeister temperaments are de facto equivalences for notations that "cut corners" in order to approximate tonality, thus cheating on the accuracy of natural tones. Eszter claims in the film that Werckmeister's temperaments are based on false foundations, and pines for a time when the Greeks could enjoy music on their "naturally tuned instrument[s]."

Rather than falling for the simplicity of the message, it is my interpretation that, instead of clamouring for a time of musical/earthly purity that preceded the separation into tones (and by extension, that of the separation into ethnicities and nations), Tarr is stating that we are living with the illusion of a clearly-defined and controllable self (hence, nation).

Further examination of Eszter as an ex-colonialist or neo-colonialist reinforces Eszter's current position as ambivalent - and this is not in Bhabha's use of the term. While Bhabha uses ambivalence to refer to the status of the occupied, or the colonized, Eszter is himself an "occupier," a former colonizer (or the metonymy thereof). This may point toward the suggestion that the colonizer inhabits the same amorphous space as the colonized; that is to say the colonizer is just as "ambivalent" as the colonized, even though focus has been shifted away from him because he is supposed to be an agent of power.

As Béla Tarr makes abundantly clear, however, even though he might be a "representative" of the fallen aristocracy, which carried out (or was a beneficiary of) the colonial process due to his very status and power, in the post-colonial era he is reduced to a pawn (even though one of the few rational ones). He becomes a lone outpost of clarity and humanity, who tries (unsuccessfully) to redress the balance set off by imprecise musical theories and colonial games. However, he fails to see the benignly monstrous "truth" under his nose as shown by his confused staring into the eye of the whale at the end of the film, which is fundamentally different from János's curious glaring indicative of revelation or at least benign wonder. In the meantime, and maybe precisely because he fails to understand the Self, Eszter cannot stop the unfolding of real threat, nor can he counterattack against his ex-wife's power-mongering schemes, which end up bringing a Real Other in charge of the town. 
Tarr's dark parable is clearly not an oblique critique of colonialism, and for this reason it stands out from the bulk of postcolonial cinema defined, among others, by Claire Denis's film work. Where Tarr succeeds is at repositioning that introspective look at our unknown, disparate, misinterpreted Selves (both as individuals and nations) at that critical moment in time when - to paraphrase Mannoni - everything started to go wrong. And again, instead of simply claiming the presence of syncretism, ambivalence and mimicry à la Bhabha, Tarr is calling for an analysis of the past without focusing on opposition, thus alluding to the offerings of theorists such as Nancy and Irigaray, who are pushing toward a reexamination of both of each other's Selves, that is those of both victim and victor, and perpetrator and subdued. This is because, not unlike Eszter, at one time or another, the roles between these two entities inevitably become blurred, reversed, and possibly superimposed over one another. Thus, for Béla Tarr the challenge to stage the ominous encounter between the Self and the Other becomes the challenge of staging the frightening encounter between Self and Self.

\section{References}

Bhabha, Homi K. 2006. The Location of Culture. New York; London: Routledge. Baudrillard, Jean. 1994. Simulacra and Simulation. Ann Arbor: University of Michigan Press.

Chassler, Philip. 2007. Reading Mannoni's Prospero and Caliban Before Reading Black Skin, White Masks. Human Architecture no. 5 (Summer): 71-81.

Chen, Kuan-Hsing. 2010. Asia as Method: Toward Deimperialization. Durham; London: Duke University Press.

Defoe, Daniel. 1883. The Life and Adventures of Robinson Crusoe. United States. Fanon, Frantz. 1968. Black Skin, White Masks. London: MacGibbon \& Kee.

Imre, Anikó. 2016. TV Socialism. Durham: Duke University Press.

Irigaray, Luce. 2002. The Way of Love. London; New York: Continuum.

Mannoni, Octave. 1956. Prospero and Caliban: The Psychology of Colonization. London: Methuen.

Nancy, Jean Luc. 2002. Being Singular Plural. Stanford: Stanford University Press. Nietzsche, Friederich. 2009. On the Genealogy of Morals. Arlington: Richer Resources Publications.

Said, Edward. 1991. Orientalism. London; New York: Penguin.

Spivak, Gayatri Chakravorty. 1999. A Critique of Postcolonial Reason: Toward a History of the Vanishing Present. Cambridge, MA: Harvard University Press. 